\title{
Contributions of Physical Activity in Individuals with a Diag- nosis of Depression: A Literature Review
}

\author{
Herick de Paula ${ }^{1}$, Elena Marie Peixoto Ruthes ${ }^{2}$, Lucca Arbigaus Gritten ${ }^{3}$, Antonio Beira de Andrade Junior ${ }^{1,3}{ }^{*}$ \\ ${ }^{1}$ Unibrasil University Center, Brazil \\ ${ }^{2}$ Federal University of Technology, Paraná, Brazil \\ ${ }^{3}$ University Center Campos de Andrade, Brazil \\ *Correspondence: antoniobeira96@gmail.com
}

How to cite this paper: de Paula, $H$., Marie Peixoto Ruthes, E., Arbigaus Gritten, L., \& Beira de Andrade Junior, A. (2021). Contributions of Physical Activity in Individuals with a Diag-nosis of Depression: A Literature Review. Open Journal of Psychology, 1(1), 32-39. Retrieved from https://www.scipublications.com/journal/index.php/ojp/article/view/191
Received: November 20, 2021 Accepted: December 24, 2021 Published: December 25, 2021

Copyright: (c) 2021 by the authors. Submitted for possible open access publication under the terms and conditions of the Creative Commons Attribution (CC BY) license (http://creativecommons.org/licenses /by/4.0/).

\begin{abstract}
This study is a literature review with a qualitative approach. It is justified by the significant increase in diseases acquired through lifestyle habits that generate health risks, which impair and are responsible for decreasing longevity and decreasing quality of life, such as hypertension, depression, obesity and respiratory tract diseases. Physical activity is recognized as a protective factor for health, and its benefits are associated with the reduction of chronic diseases and a decrease in the risk of premature death from diseases related to a sedentary lifestyle. The objective of this research is to search and identify, within the scientific literature, if there are in fact contributions from the practice of physical activity in subjects diagnosed with depression. For the categorization of studies and selection of materials, the following keywords were determined: physical exercise and depression and physical activity and depression. As inclusion criteria for data analysis and interpretation, the following were considered: articles in Portuguese, full texts, published in health journals, between the years 2005 to 2015. As exclusion criteria, we considered articles found by descriptors that did not contain one or more of the inclusion criteria. In this study, articles were selected by searching the Scientific Electronic Library Online (SciELO) and Lilacs. The choice of these databases was prioritized due to the quality and reliability of the materials available, and their easy access. 77 articles were found, of which 4 were selected to be part of this research. It can be noted that physical activity showed positive aspects and possible contributions and can be considered as a bias in an adjunct to conventional pharmacological treatments. The need for further clarification about the disease in relation to psychological, social and physiological issues is also evident, thus opening the possibility for further studies and research on the subject, so that in this way they can guide possible interventions that help in the treatment of the depression.
\end{abstract}

Keywords: Depression; Physical Exercise

\section{Introduction}

In the present study, we will address the contribution of physical activity in subjects diagnosed with depression, considering that depression is linked to the individual's mental health, we will have to first conceptualize what health would be. Using the definition of the World Health Organization (WHO), which proposes as health, the complete state of physical, mental and social well-being and not just the absence of diseases [1].

According to [2], one of the most relevant components for achieving good health is the lifestyle adopted by people, which can be understood as the actions performed by the individual in their daily lives: food, absence of drug consumption - legal and /or illegal and the practice of regular physical activities.

Being considered healthy, a diet containing the consumption of grains, vegetables, leafy vegetables; proteins in general; the daily consumption of fruits and the reduction of industrialized products rich in sodium and sugars. [3] 
As [2] points out, the practice of physical activity can be understood as any bodily movement, produced by striated skeletal musculature, which raises energy expenditure above baseline expenditure at rest, such as: locomotion activity, walking, cycling and swimming; recreational activities, games, dancing and sports; work activities, gardening, climbing stairs, housework in general. And physical exercise being conceptualized as any physical activity planned, structured and systematized that aims to develop and maintain physical capabilities, such as muscle strength and endurance, flexibility, aerobic and anaerobic capacity.

[2] emphasizes that the non-use of legal drugs such as alcoholic beverages, cigarettes, cigars, the indiscriminate use of pharmacological agents and the non-use of illegal drugs, which we can characterize as narcotics in general, are also part of the actions that can change in the subject's lifestyle.

[4] reports that regular physical activity is seen as a tool for promoting health and quality of life, helping to prevent and treat diseases. The has pointed out by [5] that physical activity is seen as health - promoting factor and that the benefits of regular practice are associated with a reduction of disease and risk factors. Even though physical activity is recognized as an important health-promoting resource, the low level and physical inactivity are alarmed at global levels.

Therefore, the objective of this research is to search and identify, within the scientific literature, if there are in fact contributions from the practice of physical activity in subjects diagnosed with depression.

This study is justified by the significant increase in diseases acquired through lifestyle habits that generate health risks, which harm and are responsible for decreasing longevity and decreasing quality of life, such as hypertension, depression, obesity and treatment of diseases. According to [6] the estimates, using the Global Burden of Disease methodology, referred to by the World Health Organization, propose that by the year 2020, depression will be one of the biggest causes not only of mortality, but also of disability in the general population. Therefore, we propose to establish the following question as a research problem: What are the contributions of physical activity in individuals diagnosed with depression?

In order to investigate the effects of physical activity on depression in the literature, we will have to characterize some symptoms present in this psychopathology disease, which commonly present sadness, low self-esteem, pessimism, recurrent negative thoughts, hopelessness and despair. Symptoms such as fatigue, irritability, withdrawal and suicidal ideation are also being presented. These symptoms usually present themselves as reactions to everyday occurrences that may be unpleasant for the subject. In this way, it can be understood as responses to psychological conflicts, situations experienced by the subject, being seen in a distorted way and distorting reality, increasing the inability of the depressed subject to socialize with other people in his life, as pointed out by [6].

[7] points out that the incidence of depression is around $17 \%$ in the world population, and it can be considered a major public health problem worldwide, taking into account its extremely high level of morbidity and mortality. Even though there are about eight classes of antidepressants and there are 22 types of active ingredients on the world market, the percentage of patients who respond positively to pharmacological treatment is only 30 to $35 \%$ of cases. Taking into account that these alarming data demonstrate that, yes, there is a need for other means to assist pharmacological treatments, which may support the reduction or elimination of symptoms of this psychopathology. It can be highlighted the problems generated, both for the population committed by this disease, as for the coffers of public health systems.

\section{Methodology}

The present study is a literature review, in this study the articles were selected by searching the Scientific Electronic Library Online (SciELO) and Lilacs. The choice of these 
databases was prioritized due to the quality and reliability of the materials available, and their easy access.

As pointed out by [8] The literature review is characterized by searches for information that has already been published in the scientific academic environment, on a specific topic. This literature can be taken from books, articles, theses, dissertations or monographs. In this way, providing a comparison of selected studies, so that the study author can present their perception, perspective or opinion on the chosen topic, based on the literature referred to in their work.

For the categorization of studies and selection of materials, the following keywords were determined: physical exercise and depression and physical activity and depression. As inclusion criteria for data analysis and interpretation, the following were considered: articles in Portuguese, full texts, published in health journals, between the years 2005 to 2015. As exclusion criteria, we considered articles found by descriptors that did not contain one or more of the inclusion criteria.

\section{Presentation of Data}

With the descriptor physical activity and depression, 51 articles were found; with the descriptor physical exercise and depression, 26 articles were found. That totaled 77 articles, 7 articles were selected after reading the title, after selection through full reading, 4 articles were selected. For a better visualization of the data mentioned above, they were listed in Table 1

Table 1. Details of selected articles

\begin{tabular}{|c|c|}
\hline Descriptors & Article numbers \\
\hline Physical Activity and Depression & 51 \\
\hline physical exercise and depression & 26 \\
\hline Total Articles Found & 77 \\
\hline Selected Articles After Reading the Title & 7 \\
\hline Selected Articles After Full Reading & 4 \\
\hline
\end{tabular}


Table 2. Presentation and discussion of collected data

\begin{tabular}{|c|c|c|c|}
\hline Author & Title & Journal (year) & Summary \\
\hline $\begin{array}{c}\text { GONÇALVES, Fel- } \\
\text { lipe Biazin et al }\end{array}$ & $\begin{array}{c}\text { Quality of life and in- } \\
\text { dicators of depression } \\
\text { in elderly women who } \\
\text { practice physical exer- } \\
\text { cises in seniors' gyms } \\
\text { in the city of Maringá } \\
\text { (Pr) }\end{array}$ & $\begin{array}{l}\text { Health and Re- } \\
\text { search, v. } 8, \mathrm{n} \text {. } \\
\text { 3, p. } 557-567 \text {, } \\
2015 .\end{array}$ & $\begin{array}{l}\text { Carried out in the city of Maringá, Paraná, Brazil, } \\
\text { the objective was to evaluate the quality of life and } \\
\text { indicators of depression in elderly women who } \\
\text { practice physical activity in elderly academies } \\
\text { (ATIs). With } 41 \text { elderly women aged } 60 \text { to } 80 \text { years, } \\
\text { who had been exercising for at least } 3 \text { months in the } \\
\text { (ATIs), they answered the following questionnaires, } \\
\text { the (WHOQOL-brefl and WHOQL-old) and the } \\
\text { (Geriatric Depression Scale). Which were the instru- } \\
\text { ments used for this study. The results showed } 80.6 \\
\text { points in the WHOQOL-brefl and } 72.6 \text { in the } \\
\text { WHOQL-old. Indicatives of depression had an av- } \\
\text { erage score of } 2.2 \text { plus or minus } 1.6 \text {, values that can } \\
\text { be considered low and positive. Being considered } \\
\text { significant and positive results in relation to quality } \\
\text { of life and depression indicators, therefore, physical } \\
\text { exercise can be a possible tool for promoting the } \\
\text { health of the elderly population. }\end{array}$ \\
\hline $\begin{array}{l}\text { BENEDETTI, Tânia } \\
\text { R. Bertoldo et al. }\end{array}$ & $\begin{array}{l}\text { Physical activity and } \\
\text { mental health status of } \\
\text { the elderly }\end{array}$ & $\begin{array}{l}\text { Journal of Pub- } \\
\text { lic Health, vol. } \\
\text { 42, p. 302-307, } \\
2008 .\end{array}$ & $\begin{array}{l}\text { Carried out in Florianópolis in 2002, with a sample } \\
\text { of } 875 \text { elderly people comprising } 437 \text { men and } 438 \\
\text { women. They were interviewed, and the BOAS and } \\
\text { IPAQ questionnaires were applied to obtain mental } \\
\text { health and physical activity data. The IPAQ data } \\
\text { show that about ( } 93.5 \% \text { ) were considered sedentary } \\
\text { in the domain of work and approximately ( } 25.7 \%) \\
\text { were considered active in the domain of leisure. Re- } \\
\text { garding mental health, there was an estimate of } \\
13.8 \% \text { for dementia and } 19.7 \% \text { for depression. I feel } \\
\text { pointed out the inverse relationship between the } \\
\text { levels of total physical activity and leisure physical } \\
\text { activity in relation to the levels of depression. }\end{array}$ \\
\hline Author & Title & Journal (year) & Summary \\
\hline
\end{tabular}




\begin{tabular}{|c|c|c|c|}
\hline $\begin{array}{l}\text { VIEIRA, José Luiz } \\
\text { Lopes; PORCU, } \\
\text { Mauro; ROCHA, } \\
\text { Priscila Garcia } \\
\text { Marques. }\end{array}$ & $\begin{array}{c}\text { The practice of regular } \\
\text { physical exercise as } \\
\text { complementary ther- } \\
\text { apy in the treatment of } \\
\text { women with depres- } \\
\text { sion }\end{array}$ & $\begin{array}{l}\text { J Bras. } \\
\text { Psychiatrist v. } \\
\text { 56, no. 1, p. 23- } \\
\text { 8, } 2007 .\end{array}$ & $\begin{array}{l}\text { Clinical trial, carried out at the Regional University } \\
\text { Hospital of Maringá, Paraná. With } 18 \text { women with } \\
\text { a mean age of } 43.66 \text { years with a diagnosis of de- } \\
\text { pression, randomly divided into two groups, a con- } \\
\text { trol group and an experimental group. All being as- } \\
\text { sessed at baseline, another assessment at the end of } \\
12 \text { weeks and an assessment } 6 \text { months after the in- } \\
\text { tervention. Structured interviews obtained data for } \\
\text { completing the Hamilton Depression Scale in the } \\
\text { 21-intensive version. - HAMD (Hamilton, 1960) in- } \\
\text { strument used to measure the levels of depression } \\
\text { in each group. The experimental group underwent } \\
\text { 12 weeks of regular exercise, using water aerobics } \\
\text { as a means, with a frequency of two weekly ses- } \\
\text { sions. Six months after the end of the clinical trial, } \\
\text { both groups were re-evaluated and, in this way, the } \\
\text { data obtained could be compared, presenting the } \\
\text { following results on the Hamilton scale } 21 \\
\text { (HAMD): Experimental group: initial assessment } \\
32.66 \text { (=3.12), evaluation after } 12 \text { weeks } 24.88(2.13) \text {, } \\
\text { and after } 6 \text { months } 29.66(3.82) \text {. Control group: ini- } \\
\text { tial evaluation 31,11(3,51), evaluation after } 12 \text { weeks } \\
\text { without the regular exercise program 30,22(3.04) } \\
\text { and after } 6 \text { weeks after the end of the clinical trial, } \\
\text { they ended up maintaining the same values. In } \\
\text { view of the results presented by the clinical trial, it } \\
\text { is noted that hydrogymnastics collaborated posi- } \\
\text { tively for the experimental group in reducing and } \\
\text { controlling the symptoms of depression, pointing } \\
\text { out its relevance and being a non-pharmacological } \\
\text { option in aid of conventional treatment with antide- } \\
\text { pressants, considering that the pharmacological } \\
\text { treatment only stabilized the depression evaluated } \\
\text { in the control group. }\end{array}$ \\
\hline $\begin{array}{l}\text { MINGHELLI, Beat- } \\
\text { riz et al. }\end{array}$ & $\begin{array}{l}\text { Comparison of anxiety } \\
\text { and depression levels } \\
\text { among active and sed- } \\
\text { entary elderly people }\end{array}$ & $\begin{array}{l}\text { Rev. psychiatr. } \\
\text { Cin. Vol.40 n² } \\
\text { São Paulo } 2013\end{array}$ & $\begin{array}{l}\text { With } 72 \text { elderly people aged } 65 \text { years or more of } \\
\text { both genders, divided into two groups, the active } \\
\text { group GA } 34 \text { elderly and the sedentary group GS } 38 \\
\text { elderly, including those who did not perform any } \\
\text { type of physical activity. Who answered a question- } \\
\text { naire about age, gender, marital status, education, } \\
\text { use of antidepressant medication and whether they } \\
\text { had any other illness. The instrument used in the } \\
\text { research to evaluate the samples was the General } \\
\text { Hospital Anxiety and Depression Scale (HAD). It } \\
\text { contains } 14 \text { items, } 7 \text { of which assessed levels of anx- } \\
\text { iety and another } 7 \text { measured levels of depression, in } \\
\text { this way the concepts of both are separated. The } \\
\text { physical exercise protocols lasted } 60 \text { minutes, with } \\
\text { warm-up, development and a return to calm. Ad- }\end{array}$ \\
\hline
\end{tabular}




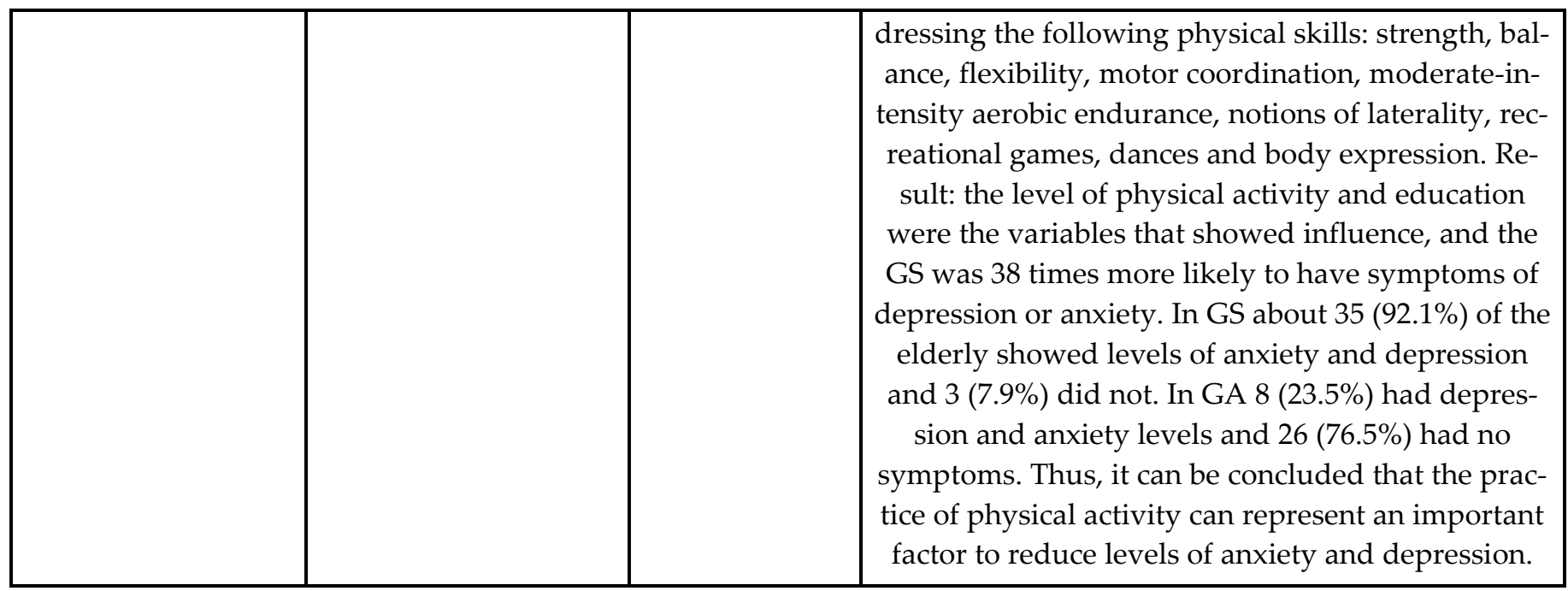

Source: The Authors 2018

In view of the table 2 presented, we could observe that the four articles used in our study have a different approach, in relation to data collection, using different assessment, measurement and research methods instruments, even so, they presented favorable results in relation to possible contributions of physical activity in depression symptoms.

Two of the four articles sought to relate, through quantitative means, the levels of physical activity with depression, comparing the data obtained through questionnaires applied in the studies, so that a questionnaire aimed to measure the levels of physical activity and the other questionnaire measuring the levels of depression in the samples. Emphasizing that in both studies, different questionnaires were used to obtain data, both for levels of physical activity and for levels of mental health.

As evidenced in the work by [6], who used the WHOQOL-brefl and WHOQL-old questionnaires and the Geriatric Depression Scale, which included 41 elderly women in their sample in the study carried out in the city of Maringá, in the state of Paraná. In the work presented by [10], the BOAS and IPAQ questionnaires were used, with a sample of 875 elderly people of both sexes. This study was carried out in the city of Florianópolis in the state of São Catarina in 2002.

Both studies indicate that the more physically active, the less likely the subject is to be affected by the symptoms of depression, and it was identified that the physically more active sample had lower scores related to depression. Similarly to the samples that had low levels of physical activity, showing high scores in relation to levels of depression, indicating an inverse relationship between physical activity and possible symptoms of depression.

We could also highlight the other two articles used in our review that have characteristics of an experimental approach. As can be seen in the study by [11], who proposed the application of a regular exercise program using water aerobics as an intervention and tests were performed at the beginning, during and at the end of the activities proposed in the study. Being applied the Hamilton scale for Depression in the 21-intensity version. HAMD (Hamilton, 1960), who assessed levels of depression in both the control and experimental groups.

[11], follows a similar approach throughout their study, applying a regular exercise program to their samples, which varied between different physical skills such as: strength, flexibility, body expression and aerobic activities, lasting 60 minutes Each session also had the participation of a control group to carry out a comparison between them, using the General Hospital Anxiety and Depression Scale (HAD) as a means of evaluating the groups. 
As we face the results obtained by the two articles in our work, we can notice a relevant decrease in the symptoms presented by the samples of the two experimental groups, which can be seen as positive responses to the programs proposed in the studies carried out. As for the control groups, no change was noted in relation to the levels of depression previously presented by the samples.

It is important to emphasize that in the study carried out by [11], the authors describe that adherence to the practice of physical activity is essential, so that there is maintenance and/or control of symptoms of depression. Considering that the symptoms commonly tend to reappear due to the absence of regular physical activity.

Such findings that are presented in the two articles above, are close to what is referred to by [7], who presents some recommendations such as: recommendations in severe cases of depression, using aerobic work, lasting between 20 to 30 minutes, with an intensity estimated between $50 \%$ to $60 \%$ of VO2max or between 12 to 14 on the Borg scale, a frequency of two to four times during the week. Proposing a functional reassessment every 10 to 12 weeks, with the objective of readjusting the training intensity. It also suggests that for people over 65 years of age, activities with aerobic characteristics lasting 20 minutes and intensity between $40 \%$ to $60 \%$ of the heart rate, or from 11 to 13 on the Borg scale, being valid three times weekly. Showing that it is relevant to emphasize that, in terms of importance, increased adherence is related to time spent with a more active life, thus presenting a correlation between physical exercise, prescribed by a trained professional and adherence to the practice by the depressed subject in search of healthier lifestyle habits.

\section{Final Considerations}

After analyzing the data, it is possible to observe that the practice of physical activity is proportionally opposed to the symptoms of depression, showing an inverse relationship between them, pointing out the need for adherence to the practice for the promotion and maintenance, not just the physical valences, but also of the individual's mental and social health.

In the same way, the positive aspects and contributions are evidenced and can be considered as a bias in an adjunct to conventional pharmacological treatments. The need for further clarification about the disease in relation to psychological, social and physiological issues is also evident, thus opening the possibility for further studies and research on the subject, so that in this way they can guide possible interventions that help in the treatment of the depression.

\section{References}

[1] Buss, P. M. \& Pellegrini Filho, A. A saúde e seus determinantes sociais. Physis Rev. Saúde Coletiva 17, 77-93 (2007).

[2] Maciel, M. G. Atividade física e funcionalidade do idoso. Mot. Rev. Educ. Física 16, 1024-1032 (2010).

[3] Sichieri, R., Coitinho, D. C., Monteiro, J. B. \& Coutinho, W. F. Recomendações de alimentação e nutrição saudável para a população brasileira. Arq. Bras. Endocrinol. Metabol. 44, 227-232 (2000).

[4] Bernardo, A. F. B., Rossi, R. C., de Souza, N. M., Pastre, C. M. \& Vanderlei, L. C. M. Associação entre atividade física e fatores de risco cardiovasculares em indivíduos de um programa de reabilitação cardíaca. Rev. Bras. Med. do Esporte 19, 231-235 (2013).

[5] Polisseni, M. L. de C. \& Ribeiro, L. C. Exercício físico como fator de proteção para a saúde em servidores públicos. Rev. Bras. Med. do Esporte 20, 340-344 (2014).

[6] Gonçalves, F. B., Araújo, A. P. S. de, Júnior, J. R. A. do N. \& Oliveira, D. V. de. Qualidade de Vida e Indicativos de Depressão em Idosas Praticantes de Exercícios Físicos em Academias da Terceira Idade da Cidade de Maringá (PR). Saúde e Pesqui. 8, 557567 (2015).

[7] Moraes, H. et al. O exercício físico no tratamento da depressão em idosos: revisão sistemática Physical exercise in the treatment of depression in the elderly: a systematic review. Rev Psiquiatr RS 29, 70-79 (2007).

[8] Boing, A. C. et al. Metodologia da pesquisaBoing, A. C. et al. Modalidade a Distância Especialização em UNA-SUS Saúde da Família Eixo III-Gestão e Avaliação na Estratégia Saúde da Família Módulo 19: Metodologia da Pesquisa. 
[9] Benedetti, T. R. B., Borges, L. J., Petroski, E. L. \& Gonçalves, L. H. T. Atividade física e estado de saúde mental de idosos. Rev. Saude Publica 42, 302-307 (2008).

[10] Vieira, J. L. L., Porcu, M. \& Da Rocha, P. G. M. A prática de exercícios físicos regulares como terapia complementar ao tratamento de mulheres com depressão. J. Bras. Psiquiatr. 56, 23-28 (2007).

[11] Minghelli, B., Tomé, B., Nunes, C., Neves, A. \& Simões, C. Comparison of levels of anxiety and depression among active and sedentary elderly Comparação dos níveis de ansiedade e depressão entre idosos ativos e sedentários (2013). 